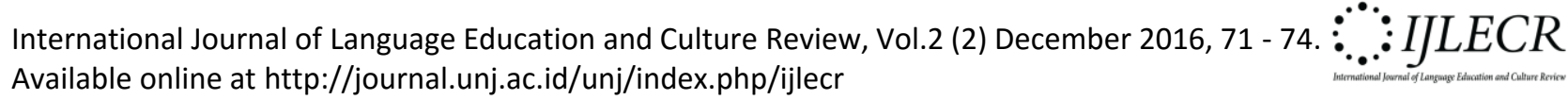

DOI:doi.org/10.21009/IJLECR.022.09

\title{
IMPROVING ENGLISH SPEAKING ABILITY THROUGH MOBILE ASSISTED LANGUAGE LEARNING (MALL) LEARNING MODEL
}

\author{
Muhamad Sofian Hadi ${ }^{1}$, Emzir ${ }^{2}$ \\ Muhammadiyah University of Jakarta ${ }^{1}$ \\ Universitas Negeri Jakarta, Indonesia ${ }^{2}$ \\ m_sofianhadi@yahoo.com ${ }^{1}$ \\ emzir.pb@gmail.com²
}

\begin{abstract}
The aims of the study to reveals in details process and result of improving English speaking ability using Mobile assisted Language Learning (MALL) learning model. This study is an action research at English Department Muhammdiyah University of Jakarta consists of 30 students as the participant. Data obtained from the result of English Speaking ability test. The results of the study showed that the learning process using Mobile Assisted Language Learning (MALL) makes the students become more active in their speech; their participation level in learning interaction shows it. The result also presented that there is significantly improvement on the students' English speaking ability using Mobile Assisted Language Learning (MALL) from preliminary cycle to the third cycle phase in research process. The average score of the students at preliminary stage is only 42.8 then it increased in the first cycle to 53.2. While on the second cycle obtained an average score of 61.2 and increased in the third cycle to 80. So, it can be concluded that action research in improving English speaking ability using Mobile Assisted Language Learning (MALL) significantly helps the students in improving their ability to speak English.
\end{abstract}

Keywords: Speaking, Learning Model, Mobile Assisted Language Learning (MALL)

The ability in speaking is one of the ability should be mastered by everyone, mastering English language will give various benefits in learning English especially speaking that give the big impact for the students, when they can communicate in a good way its mean the objectives of learning English speaking is accomplished.

The ability to speak English is also one of the subject that students should learn and also become one of the most difficult lesson to mastered, this statement is supported by Bueno, Madrid and Mclaren that states "speaking is one of the most difficult skills language learners have to face (2006:321. That's why new learning model have to change simultaneously.

Another opinion by Iskandarwassid (2009:241) explained that speaking ability is an ability to produce articulation sounds system to deliver will, needs, feeling to other people. While Harmer (2007:343) mentioned that to be a good and fluent English speaker, students have to pronounce the phonemes in appropriate way, correct stressing, intonation and talking about the linking content.

The ability of speaking English will increase if the learning model used based on the needs. One of the learning models that can be used to help speaking class at Muhammadiyah University of Jakarta is Mobile Assisted Language Learning (MALL). This learning model is the development of blended learning.

The benefit of using technology according to Cabanban in his research (2013) is the use of smartphone as the part of lifestyle in Indonesian society, the function of smartphone is not only to communicate but transformed into the tools that used to socialize, entertaining and learning.

Cinnery (2006) explains some advantages of using Mobile Assisted Language Learning (MALL) as its availability, portability and lower cost compared to the use of Computer Assisted Language Learning (CALL). The aims of this study are to reveals the process and result of improving English speaking ability through Mobile Assisted Language Learning (MALL) Learning model. 
Some previous study deals with the use of technology in learning as mentioned by Burnston (2012) about Mobile Language Learning: Getting IT to work. Kukulska-Hulme. A. \& Traxler J ( 2007) also discuss about the use of Mobile Learning. The studies focus on the advantages of using mobile gadget in learning process.

Chu. $\mathrm{H}$ (2011) also poses a result of the study about the effect of using smartphone in learning vocabulary. While Brown (2012) discuss about the use of tablet in developing understanding of digital literation in learning process in classroom. From some discussion above, the researcher decided in conducting a research deals with the use of Mobile Assisted Language Learning (MALL) in improving speaking ability (An action research at English Department Muhammadiyah University of Jakarta).

\section{METHOD}

This research is an action research with numbers of participant 30 students from third semester of English department at Muhammadiyah University of Jakarta. The research stages consist of three cycles based on the need of research process. The successful of the use Mobile Assisted Language Learning (MALL) in improving students speaking ability can be shown from the increasing of students' scores each cycle.

\section{FINDING AND DISCUSSION}

Based on action research on improving students' speaking ability using Mobile Assisted Language Learning (MALL) learning model, the obtained research findings on the third cycle. The findings of that study concluded based sources of qualitative data from observations of the lecture held at each meeting of the first cycle to the third cycle.

In preliminary tests that have been carried out by researchers there are ten people $(33 \%)$ of students who scored with less than satisfactory category, while twenty people $(67 \%)$ of students who received scores in the category of very less.

As for the comparison of each cycle of the first cycle to the third cycle can be explained in the following diagram:

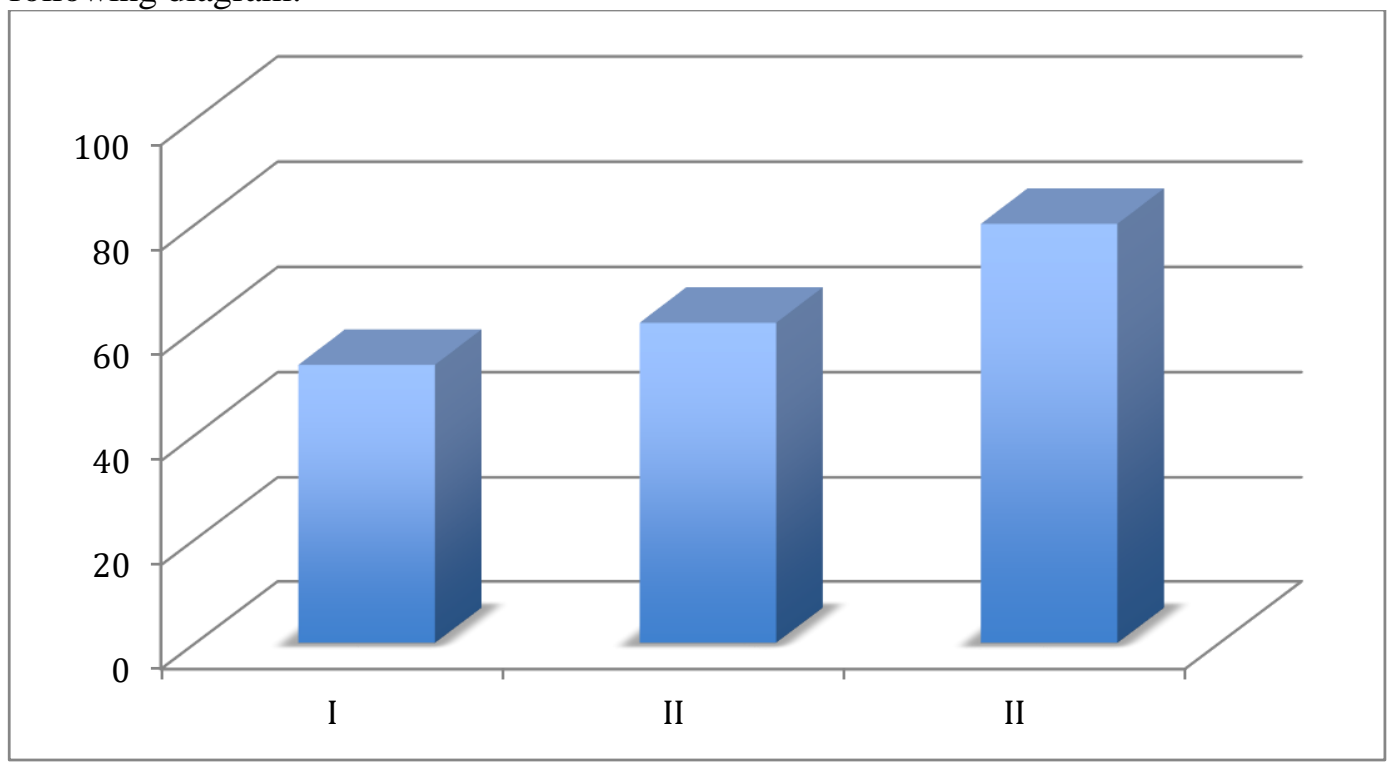

\section{CYCLES}

From the diagram above it can be explained in the first cycle there are six people (20\%) who received satisfactory scores in the category, while six people $(20 \%)$ of students scored in the category of very less. The remaining eighteen $(60 \%)$ scored unsatisfactory category.

In the second cycle obtained data on the learning process as follows, as much as two people (7\%) of students who received grades in the category of very less, while fifteen people (50\%) of students scored 
in the category less than satisfactory, the remaining thirteen (43\%) of students scored in the category was satisfactory.

In the third cycle of data obtained following results, there is one (3\%) of students who scored in the unsatisfactory category, while as many as seventeen people (57\%) of students scored in the category was satisfactory. The remaining twelve (40\%) of students scored at a satisfactory category.

In the process of learning to use Mobile Assisted Language Learning (MALL), the score of the test results speak English students have been analyzed with regard to aspects of the assessment criteria which include pronunciation, vocabulary, grammar, fluency and style.

In the first cycle, most students still have not been able to make the description in accordance with instructions given by a lecturer of the course. But there are also some students who have been able to make a description even though still in a satisfactory category. The results of the action in the first cycle were obtained from 30 students, showed existing test scores increase the ability to speak English. If the initial tests preliminary phase of the average score obtained by the students increased by $42.8 \%$ to $53.2 \%$ at the end of the test cycle I. But the minimum passing criteria are set at $75 \%$ yet to be met, thus requiring advanced cycles for get a better improvement again.

The results of the action on the second cycle were obtained from 30 students showed existing test scores increase the ability to speak English. If in the first cycle the average value obtained for 53.2\% of students. So at the end of the second cycle test score average score obtained student has reached $61.2 \%$ and in the category was satisfactory.

While the ability of students in the third cycle were obtained from 30 students showed excellent results and satisfactory. This can be seen in the improvement that occurred from the average score of students in the second cycle that only amounted to $61.2 \%$ and then experienced a significant increase with a rate of $80 \%$. It's certainly already exceeded the target achievement of the research that is equal to $75 \%$, so it is not necessary to mention the cycle continued. Due to the results obtained from a series of three cycles that have been done already get satisfactory results.

Based on the analysis above it can be interpreted that the students' speaking ability can be improved by using Mobile Assisted Language Learning (MALL) Learning Model. Improvement occurring by using model MALL can be seen from the preliminary stage, the first cycle, second cycle and third cycle respectively increased from the score of students who still fall into the category of less than satisfactory in preliminary and the first cycle, and then to be quite satisfactory in cycle stages II and became satisfaction at this stage of the cycle III.

The limitations of this study include some of the following:

1. The materials given to students cannot be explained thoroughly to the stage finish.

2. In action research, there are some students still tend to be busy with their own activities.

3. Some of the task collected students still incomplete.

4. Smartphone owned by the students still has difficulty accessing applications easily.

\section{CONCLUSION}

Process in improving Speaking with MALL

In implementing of learning models Mobile Assisted Language Learning (MALL) in learning to speak English has increased student involvement. Involvement in their learning tends to increase it is characterized by the response they give to the lecturer of the course, actively asked when they do not understand the material that being studied, trying to find answers independently with their smartphone device to use the internet, do the tasks given, serious in doing, and do not forget to do homework that is given to them.

1. Results in Improving Speaking with MALL

a. The results cycle I obtained from 30 students showed an increase in test scores of students' speaking ability. If at the beginning of the preliminary test earned an average score of 42.8 , at the end of the first cycle test scores on average had reached 53.2. 
b. The results of the second cycle were obtained from 30 students showed an increase in test scores of students' speaking ability. If the test cycle I obtained an average score of 53.2, at the end of the test cycle II, the average score has reached 61.2.

c. The results of the third cycle of action obtained from 30 students showed an increase in test scores of students' speaking ability significantly. In the second cycle tests obtained an average score of 61.2 , at the end of the third cycle test score average is 80 .

\section{REFERENCES}

Brown, M. 2012. Tablet computing to cultivate Japanese EFL digital literacy: A study on video production in the classroom. In J. Colpaert, A. Aerts, W-C. Vivian Wu, \& Y-C. Joni Chao, (Eds.), The Medium Matters (Proceedings 15th International CALL Conference)

Burston, J. 2012. Mobile language learning: Getting IT to work. In J. Burston, F. Doa, \& D. Tsagari, (Eds.), Foreign language instructional technology

C.L.G. Cabanban. 2013. Development of Mobile Learning Using Android Platform. International Journal of Information Technology \& Computer Science (IJITCS), May/June, 2013, Volume 9, Number 1 .

Chu, H. 2011. The Effect of the Features of Smart Phone Vocabulary Applications on Korean College Students' Satisfaction and Continued Use. Multimedia-Assisted Language Learning, (14(2), 91112)

G.M Chinnery. 2006. Emerging Technologies Going to MALL: Mobile Assisted Language Learning. (Language Learning \& Technology. Volume 10. January

Harmer, Jeremy. 2007. The Practice of English Language Teaching: The Forth Edition. Cambridge: Pearson Education Limited.

Iskandarwassid dan Dadang Sunendar. 2009. Strategi Pembelajaran Bahasa. Sekolah Pascasarjana Universitas Indonesia.

Kukulska-Hulme, A. \& Traxler, J. 2007. Mobile learning: A handbook for educators and trainers. Oxon: Routledge.

Madrid, Bueno, A, D and N. McLaren. 2006. TEFL in Secondary Education. Granada: Editorial Universidad de Granada. 